\title{
YEATS'S REDEFINITION OF POETIC SELF IN NATURE SYMBOLISM
}

\author{
Azra Ghandeharion \\ Ferdowsi University of Mashhad, Iran \\ Maryam Sadat Mousavi Takieh \\ Ferdowsi University of Mashhad, Iran
}

\begin{abstract}
William Butler Yeats has been always attracted to mythology and its affinities with poetic creation. Besides, nature has played an influential role in his art. Benefiting from archetypal approach, this paper tries to cast light on Yeats's definition of soul's eternity and poetic self. Poet's quest and his creative art are reflected by a set of nature symbols like swan. Through confrontation with nature, examining it as a source of ideas, motifs, and myths, Yeats sheds light on his interior state of self to create art. For him, art is a means of self-realization. It is concluded that his poetic contemplations on the inevitable changes of life, reflected in the macrocosm of nature, offer both the writer and reader a fuller vision of reality.
\end{abstract}

Keywords: William Butler Yeats; Archetype; Poetic Self; Nature;

\section{Introduction}

Partly conscious and relatively subconscious, it seems that mythopoeic writers like William Butler Yeats are carefully structuring their works on myth (Guerin, et. al., 199). Myth "is a dynamic factor everywhere in human society; it transcends time, uniting the past (traditional modes of belief) with the present (current values) and reaching toward the future (spiritual and cultural aspirations)"(Guerin, et. al., 184). Universal symbols or archetypes reflected in legend, folklore, and the ideology of a nation provide as much impetus for those poets who are willing to soak their imagination in the dreams and myths of their nations. For Allen, the "most myth-conscious and archetype-oriented poets of the day has suffered misinterpretation upon misinterpretation" because "analytical structures thoroughly foreign to the shape of [their] imaginative thought" have been imposed on them (62). He considers mythopoeic analysis and archetypal criticism as the most reliable approach to "Yeats's philosophical convictions, symbolic methods, and expansive imaginative vision" (ibid.). However, it is not Allen but Wheelwright's contribution who leads us directly to the archetypal approach to the poetry of Yeats. This paper shows how Yeats's swan and nature iconography transcend time because they are transmuted into archetypal images that are the symbolic projections of mankind's desire to eternalize the experience of beauty.

\section{Archetype}

An archetypal image reflects motifs that underlie human behavior. Archetype is the "dramatic representation of . . . a primary awareness of man . . . upon which all particular attitudes and opinions depend" (Schorer 29). In this case, an archetypal image is by nature collective and communal. It is the "expression of profound sense of togetherness of feeling and of action and of wholeness of living" (Tate 11). Therefore, an archetypal image is omnipresent in time as well as place. Archetype is the original pattern or model 
from which all entities of the same kind are copied or on which they are based. In Jungian psychology, archetype is a collectively inherited unconscious idea, pattern of thought, image, etc., universally present in individual psyches. Therefore, in an archetypal image, consisting of repeated motifs and themes, one can find the traces of past as well as present with the possibility of continuation and variation in those patterns in future.

\section{Asserting Eternity through Art}

Yeats who ardently aspires to "translate his intellectual [and archetypal] symbols into outward and visible signs" publishes his collection of lyric poetry The Wild Swans at Coole in 1919 (MacNeice 108, 129) and round the home of the Gregorys he builds his mythology. Sifting through the theme of the whole volume, in fact, in the labyrinth of his entwined symbolism, one might sense that "the restoration of wholeness in the book is, in other words, the poet's reaffirmation of his will to art" (Miyake 49) which is a form of asserting eternity. The figurative title poem in the volume "can be taken as a symbol of the whole book to illuminate its entire design" (Miyake 52). "The Wild Swans at Coole" (1917) follows the myth of immortality against a background imbued with temporality (Abrams 2101).As "a realist-symbolist-metaphysical poet "who tries" to fix sublime emotions in the form of poetry" (Abrams 2088; Miyake 49), he finds their realizations by fusing occultism, mysticism, Irish mythology, use of symbols and theory of the mask (Azam 1). Therefore, to restore the balance of time that is lost in the collapsed community of de-religious modernism, Yeats calls for images of eternity in this poem.

\section{Yeats's Affinity with Nature}

Standing upon the threshold of decline, brooding on awesome temporality yet in ardent quest for perpetuity, Yeats is still unmarried at the age of fifty-one. Being in the autumn of his life, he gives integrity as a poet to his images by showing his semblance to the nature, more intensely shown in autumn season: "The trees are in their autumn beauty"( 1 . 1). From the first stanza onward, the poet draws upon a fundamental motif in myth--immortality---by using the image of tree. For Cirlot, tree is the "inexhaustible life, and is therefore equivalent to a symbol of immortality" (qtd. in Guerin, et. al., 189). Immortality is represented in the color of autumnal leaves, which are gold signifying "the state of glory" (Cirlot 56) in nature. Trees are seen as the only place that a man can escape from his mortality (Gates, par. 2). This majestic beauty of gold "corresponds to the mystic aspect of the sun" (Cirlot 53) which epitomizes "life force, creative-guiding force, brightness, splendor, active awakening, healing, resurrection, ultimate wholeness" (Lawrence 3). Thus, Yeats's desire in reaching wholeness is manifested in all minute parts of the poem.

The beauty of that scenery is intensified with "Under the October twilight the water /Mirrors a still sky;" (1. 3-4). Yeats works upon the images that let time flow into eternity, intensified with the image of water representing the "perennial response" of the cycle of "birth-death-resurrection" (Guerin, et., al. 182, 185). This ideal archetypal image in Yeats's poems "symbolizes the human soul for its reflectiveness and depth. When it comes to water element, the poet's mind grows still, receptive and keen. His whole being waits for the illumination of truth to come" (Miyake 51).More important, Yeats organizes water and its image to build upon the central symbol of the poem --- the swans:"Upon the brimming water among the stones/Are nine-and-fifty swans" (1. 5-6).Viewed from a slightly different archetypal angle, these symbolic implications are suggesting father- 
mother principle. The sun, "father principle" evaporates sea that is "the mother of all life" (Guerin, et., al. 185). Water (mother, life) is condensed in clouds and returns to earth, "a female principle" (Cirlot 56), in the form of life-giving rain. This image per se along with the image of the swans flying away in the last line of the final stanza show that Yeats's love for Maud Gonne is symbolically represented in natural scenery. As the sun, stands above the female entity (i.e. water), probably Yeats has managed to stand above the love of his ex-beloved Maud Gonne. That is why critics like Levine claim, "his obsession with Maud Gonne seems to have been brought under control since he is able to distance himself from her" (411).Between 1915-19, as David Young argues, Yeats is "more often present as a master of his art and life." (qtd. in Levine 411).

He grows older as his poetry grows younger (MacNeice 122) in his path to welcome the new birth as well as change and mutability. That is why from the very beginning of this poem (i.e. $1^{\text {st }}$ stanza), beauty and permanency is an inseparable part of art while "there is a hint of change, a creation of instantaneous nostalgia, in a beauty which is part of autumn and perceived in "October twilight"' (Hahn 419). Also in the fifth line of the opening stanza, the idea of change and mutability shrewdly pushes itself into the realm of nature. Nature is prone to change; because of its fluctuating quality, nature cannot thoroughly reflect the ethereal eternalized beauty that the poet seeks (Gates, par. 3). Thus, Yeats shows overflowing of water in "brimming" (1. 5). Later, he continues, "The woodland paths are dry" (1.2) that can imply the idea of unproductivity and barrenness of poet's dreams. One can draw biographical inferences to intemperate these lines: his refusal of marriage proposal to Maude Gonne in 1916 (Jeffares 31) has happened at the threshold of composing this poem. That is another natural clue, one of the representatives of many symbols used by Yeats indicating transitional phase of the life cycle. After "a long barren passion for a marriage" (Jeffares 33) which is disappointing to the continuation of Yeats line, in 1917, he marries Miss Georgie Hyde-Lees. In this phase, "attempts to formulate his astrological and occult speculations into a 'system' also date from this time, for his wife had the gift of 'automatic writing', a fact which delighted Yeats" (Cowell 53).

The poet makes the scene more visual and vivid by revealing that fifty-nine swans, symbolizing "the life-force" , "the state of perfect harmony," and "eternal life, permanent beauty and immutability" are floating on water (qtd. in Miyake 51; Billigheimer 56-57). Yeats's use of the archetype of the swan can be explained through his fascination with the Irish legend, the story of two lovers Baile and Aillinn who are transformed into swans, well reflected in his earlier poem "Baile and Aillinn" (1903) (Abrams 2101). "From their role as immortal lovers in the dream-like magical world of Irish mythology, swans evolve into a more dramatic and complex mythological symbolism in The Wild Swans at Coole, both on a personal level and in a universal dimension" (Billigheimer 55). The swans can be taken as the representative of the élan vital of youth as well since "their hearts do not grow old, they find the streams companionable despite their coldness, passion and conquest attend them unsought, and their vigor is such that they climb the air instead of flying through it" (qtd. in Miyake 51). Since swans mate for life, fifty-nine swans imply that one has lost a mate. The archetypal significance of number fifty-nine can be interpreted as the combination of five, one, and twelve regarding Cirlot's number symbolism (i.e.; [12*5]$1=59$ ). Five is the symbolic harmony and integration, "Man, health and love"; one is "the mystic Center" of the dream of Irish identity; additionally, twelve means the "cosmic order and salvation" that Yeats as an artist tries to bring for his nation (232-4). Yeats's 
combination seems meaningful as the fusion of five, twelve and one happens in his poem $[(12 * 5)-1=59]$. He is preoccupied with an image of a modern man who is "disillusioned due to mechanization" and lives in an age where "romances were coming to an end and people were getting brutal" (Azam 2). Disillusioned as a modern man and witnessed the "lack of harmony and strength in modern culture, Yeats [have] tried to revive the ancient spells and chant to bring unity and a spirit of integration in modern civilization torn by conflicts and dissensions" (ibid.). He tries to be the prophetic poet who can make sixty out of fifty-nine. It seems that Yeats stands in the center of the universe of his art. That is why he is able to bring order, peace, hope and spiritual salvation to his life and above all to Ireland. It is similar to the poet's life since he used to love Maud Gonne, the Soul Mate, "the princess or 'beautiful lady'-incarnation of inspiration and spiritual fulfillment" (Guerin, et. al., 187) who refuses to marry him. Therefore, the single swan represents Yeats. And the missing swan is Maud Gonne who can be associated with the stunning image of the swan (Levine 411). By composing the poem, Yeats "finally learned to release the nine-and-fifty swans at Coole from his private obsession, freeing them and all later swans in his poetry to become universal symbols for his readers" (Levine 411).

In this poem, Yeats tries to compare two visits that he made to Coole Park, Lady Gregory's country estate: one in 1897 and the second in 1916. Lady Augusta Gregory, Yeats's friend and patron, for whom he feels indebted for paving the way to regenerate Ireland's national identity is responsible for bringing persistent nobility to his uncertain thoughts (Cowell 26-27). Lady Augusta Gregory also epitomizes the Good Mother (i.e. good aspects of the Earth Mother) which means that she's "associated with the life principle, birth, warmth, nourishment, protection, fertility, growth, abundance" (Guerin, et. al., 187). As the result of her patronage, the influence of the Celtic Renaissance is vividly felt in Yeats' early poetry centering on Irish folklore, legends, and traditions. One such symbol which Yeats borrowed from Irish legend was the swans and The Wild Swans at Coole owes a great deal to the influence of Irish tradition. In his quest for timelessness, Yeats strives impatiently to solve the challenging riddles and pass the insurmountable obstacles: the passage of time. Being change-sick and aware of human transience, he writes of "the particular loneliness and mutability he has experienced in his own life"(Gates, par. 12) most notably seen in line fifteen "All's changed" (1. 15). He idolizes the swans because as Yeats feels the burden of change in this phase of life, swans are "empirical presences like himself," yet "they can never be aware of weariness, of transience or of decline" (qtd. in Gates, par. 4). Yeats's first task "is to cultivate a cold, austere control so that he does not succumb to the commercial spirit, to sentimentality, or to philosophies that imprison either will or intellect" (O'Brien 2). His heart is torn by the death of his friends and the wound of Maud Gonne is not still healed, yet "he skillfully guides his emotion and thought into artistic molds" (ibid.). He undergoes this superhuman feat by presenting an idyllic picture of a landscape in the first stanza of the poem, making out of nature a resort, where no materiality and concerns can enter the domain of human life and torment his mind.

Distancing himself to represent an impersonal description of natural scenery, from the second stanza to the fifth, the poet's voice is heard. That is interpreted as Yeats's "forceful juxtaposition of his own experience of fleeting time with the permanence he seeks" (Gates, par. 1). The "transpersonal nature of beauty" (ibid.) pictured in the final stanza of the poem "Mysterious, beautiful" (1. 26) exhibits poet's ideal crave to seek 
permanent beauty in temporality. However, "a part of these temporal changes"(Gates, par. 5), fifty-nine swans "All suddenly mount/And scatter wheeling in great broken rings/ Upon their clamorous wings" (1. 10-12) before the poet can finish his counting. Even in their stillness and tranquility, these wild swans "harbor the instinct of flight" and in "their tableau of permanence, the element of change [is inherent]" (Hahn 419-20). The swans form a ring, "a symbol of eternity--and perhaps this reminds Yeats that while he might change, the swans remain the same, and even make the same patterns in the sky every year" (O' Driscoll 2). All of these images constitute a special message that the poet tries to show the reader. Here Yeats breaks the overwhelming sense of immutability of nature. He transfers this idea that "through the window of the swans, the poet sees the possibility of temporal beings transcending 'transience' and 'decline' in an attainment of eternal beauty" (Gates, par. 5).

Influenced by "the seeming permanence of the swans and the drastic decline of his own strength" (O'Brien 2), Yeats continues: "I have looked upon those brilliant creatures, /And now my heart is sore" (1.13-14). Yeats is haunted by the impression of change; that's why he uses "All's changed" (1.15) since his first visit, when he "trod with a lighter tread" (1. 18), not yet drown in a sea of time-bound existence. Now sore at his heart, he envies the swans that he thinks they can defy time. Unlike the poet, they are "Unwearied still, lover by lover" (1. 19) "Passion or conquest, wander where they will, /Attend upon them still" (1. 23-24). Devoid of companionship, passion or conquest, the poet may think these are the elements that can eternalize happiness in his heart, now old and wearied.

The poet reluctantly acknowledges his inevitable mortality in the final stanza, ". . . when I awake some day" (1. 29) thus making out of himself a sacrificial scapegoat so that with the alchemy of his art, here poetry, "Delight [of] men's eyes" (1. 29) rests on his creation. He must die to atone for the pall of time-bound interactions hanging over his entire earthly kingdom. His death leads to the rebirth of younger swans, younger generation, young poets, and young Irishmen. So youth and immortality are happily wedded to Irish nation, represented "as 'soft wax' which could be given shape, purpose and beauty by a literary renaissance" (Cowell 22). The poem is concluded with a question to highlight the uncertainty of the future against the dominant image of eternity: "Among what rushes will they build, /By what lake's edge or pool/Delight men's eyes, when I awake some day/To find they have flown away?"(1. 27-30).

The last image of the poem leads the reader to this conclusion that the poet willingly opens a more optimistic window to the world, letting the breeze of hope caress his cheeks on an autumnal day by his art of poetry. He comes to embrace an image of permanence by the fifty-nine swan pattern: "the old swans are replaced by younger ones, ... . A swan dies, but the swans live, and as the new are indistinguishable from the old, the swans become an intricate symbol of youth, forever passing yet forever renewed" (Gilbert 47). Interestingly, this eternity is not confined to poet since in the context of his poem, when he awakes one morning, the wild swans have flown away to delight the eyes of other men.

The image of swans gives integrity and meaning to the apparently senseless "great broken rings" of change (1 .11). When the protagonist of the poem experiences loss, he finds swans as the consistent message of beauty and eternity (Hahn 420). Seen from another angle, this image of ephemeral timelessness can represent the state of blissful immortality enjoyed by Adam and Eve before their Fall into the world of corruption and death. Interestingly, The Wild Swans at Coole poetry collection includes a group of poems 
about the value of art. Through this volume, Yeats "develops a positive attitude to time, age and death, an attitude based on the primacy of the heart and the concept of intensity in art and life" (Cowell 59). Yeats believes that "through art and literature man can make himself more than the trembling victim of incomprehensible forces such as age and death" (ibid. 61). Surly, Yeats and all people following his symbolism in art are "now going to gain a new passage to life through [their] search into the biggest inevitability of nature, death" (Miyake 52).

\section{Conclusion}

In "The Wild Swans at Coole," Yeats articulates his thirst for eternity through archetypal images. Through confrontation with nature, examining it as a source of ideas, motifs, and myths, Yeats sheds light on his interior state of self bewildered by torments of the past. Aware of predetermined dynamism of symbols and images, he draws them from nature, Irish folklore and mythology to illuminate his sense of the plights of a modern man exposed to the tragedy of collapsing of modern civilization due to brutalities of the First World War. Knowing of more crisis in the offing, the poet attempts to curb all the disasters, whether natural, national or global through the healing power of his imaginative art. Tormented by the atrophy of old age, however, the poet aspires to defy time through his quest for passionate desires. Thus, he makes no demur to capitalize on "nature as his anti-self" to embody "a fuller vision of reality grasped by his whole new being" (Miyake $54,59)$. Surviving from an emotional crisis, this time he tries his best to absorb the élan of the world of symbolism in order to capture the powers of eternity. Through his portrayal of the swans, Yeats attempts to lead his contemplations on the inevitable changes due to aging and thus offers a fuller vision of reality.

\section{References}

Abrams, M. H. (2000). "William Butler Yeats." The Norton Anthology of English Literature. 7th ed. Vol. 2. New York: W. W. The Norton \& Company, Inc.

Allen, Lovic James. (1973). "The Road to Byzantium: Archetypal Criticism and Yeats." Journal of Aesthetics and Art Criticism 32.1: 53-64. JSTOR. Web. 19 Oct. 2013.

Azam, Mohammad. (2011). "W. B Yeats--A Modern Poet." Slideshare.net. Web. 30 Oct. 2013.<http://www. slideshare.net/Muhammad786/w-b-yeats-as-a-modern-poet-8655481>.

Billigheimer, V. Rachel. (1986). ““Passion and Conquest”: Yeats' Swans.”. College Literature 13.1: 55-70. JSTOR. Web. 9 Oct. 2013.

Cirlot, J. E. 2002. A Dictionary of Symbols. Trans. Jack Sage. New York: Philosophical Library.

Cowell, Raymond. (1969). W. B. Yeats. London: Evans Brothers Limited.

Gates, Andrew. (2010). "The Wild Swans at Coole. "The Modernism Lab at Yale University. Yale University. Web. 2 Oct. 2013. <http://modernism.research.yale.edu/wiki/index.php/The_Wild_Swans_at_Coole>.

Gilbert, Sandra. (1965). The Poetry of W. B. Yeats. New York: Monarch Press.

Guerin, L. Wilfred, Earle Labor, Lee Morgan, Jeanne C. Reesman, and John R. Willingham. (2005). A Handbook of Critical Approaches to Literature. $5^{\text {th }}$ ed. New York: Oxford University Press.

Hahn, M. Norma. (1961). "Yeats's 'The Wild Swans at Coole': Meaning and Structure." College English 22.6 :419-21. JSTOR. Web. 9 Oct. 2013.

Jeffares, A. Norman. (1976). The Poetry of W. B. Yeats. London: Edward Arnold.

Lawrence, Lisa. "Common Archetypes and Symbols in Literature. AP Lang Gonzo.Muhsd.k12.ca.us. Merced Union High School District. Web. 21 Oct. 2013. View shared post<http://www.muhsd.k12.ca.us/cms/ lib5/CA01001051/Centricity/Domain/520/English\%203/Unit\%201\%20\%20Early\%20American\%20 Lit/ArchetypesandSymbols.pdf $>$.

Levine, J. Herbert. (1981). “Freeing The Swans': Yeats's Exorcism of Maud Gonne.”ELH 48.2:411-26. JSTOR. 
MacNeice, Louis. (1967). The Poetry of W.B. Yeats. London: Faber and Faber.

Miyake, Nobue. (1999). "The Restoration of Wholeness in The Wild swans at Coole." The Harp 14: 49-59. JSTOR.

O’ Brien, H. James. (1968). "Yeats's Discoveries of Self in The Wild Swans at Coole."Colby Quarterly 8.1: $1-13$. http: // digitalcommons.colby.edu/cq>.

O' Driscoll, Aoife. "Yeats Notes."Aoifesnotes.com. Web. 5 Oct. 2013.<http://www.aoifesnotes.com/leaving-cert/ordinary-level/Paper-Two/docs/prescribed-poetry/Yeats\%20Notes.pdf $>$.

Schorer, Mark. (1946). William Blake: The Politics of Vision. New York: Holt.

Tate, Allen. (Ed). (1960). The Language of Poetry. New York. Russell.

Yeats, W. B. "The Wild Swans at Coole." The Norton Anthology of English Literature. 7th ed. M. H. Abrams, ed. Vol. 2. New York: W. W. The Norton \& Company, Inc. 2000. 2101. 